\title{
PEMENUHAN HAK KEBUDAYAAN DAN KEPARIWISATAAN WISATAWAN PENYANDANG DISABILITAS FISIK DI KOTA BATAM
}

\author{
Winsherly $\operatorname{Tan}^{1}$ \\ Annisa Putri Sabila Hasibuan ${ }^{2}$
}

\begin{abstract}
Batam is rapidly developed nowadays. There are factors that might effect the growth. The effort of promoting tourism and cultural programs, and the envolvement of tourism parties, are made to attract more tourists to visit Batam. However, beside the growth of tourisms itself, the government and responsible parties are laxing to provide and maintain good facilities for tourists. Because, tourist has their own right as a tourist, which is regulated in Undang-Undang Republik Indonesia Number 8 Year 2016 about Person with Disabilities, and it is called the cultural and tourism rights.

Therefore, this dissertation is aimed to find out about the tourist visits potency in Batam, and to find out about what's the real obstacles, faced by both people with disability (phiysically) and the government, due to the effort of fulfilling cultural and tourism rights.

The writer is using the empirical method in analyzing the collected data, where the data itself was collected while doing the interview or observation. Then, the writer describe the matters in tie with regulations.

By then, it can be seen that the tourism potency of Batam is great, but unfortunately, data lacking toward disabilities show that the government has not yet put the issue in the first place. The problems is now remain unidentified as the data was out of record. So, the government efforts in the future with both tourism business field persons and nearby community is now concerned and hopefully can improve the quality of accessibilities that has been built, in progress, or will be built in the future.
\end{abstract}

Keywords: Business Competition, Comparative Law, Settlement of the Case.

\footnotetext{
${ }^{1}$ Fakultas Hukum Universitas Internasional Batam

${ }^{2}$ Fakultas Hukum Universitas Internasional Batam
} 


\section{A. Latar Belakang}

Pulau Batam ialah salah satu pulau terluar di Indonesia yang berbatasan langsung dengan teritorial laut Singapura dan Malaysia. Hal ini kemudian melahirkan harapan baru untuk mengembangkan potensi pariwisata di Kota Batam. Kondisi geografis ini didukung oleh mudahnya akses transportasi laut menggunakan kapal Ferry. Kota Batam menawarkan tempat-tempat menarik untuk wisatawan mancanegara maupun wisatawan lokal. Berdasarkan data Badan Pusat Statistik Kota Batam, dalam tiga tahun belakangan, kedatangan wisatawan mancanegara melalui pelabuhan udara dan laut terus meningkat. Pada tahun 2016, wisatawan yang datang ke Kota Batam sebanyak 1.422.949 jiwa, sedangkan pada tahun 2017 mengalami peningkatan yakni sebanyak 1.507.273 jiwa. ${ }^{3}$ Hingga November 2018, tercatat sebanyak 1.654.091 jiwa wisatawan mancanegara yang berkunjung ke Pulau Batam dengan wisatawan mancanegara terdekat yakni Singapura mencapai angka 1.121.932 jiwa dan Malaysia mencapai 273.373 jiwa. ${ }^{4}$

Namun, dari banyaknya wisatawan yang berkunjung ke Batam, tentu ada sejumlah wisatawan yang memiliki keterbatasan dalam melakukan kegiatan terkait pariwisata di Batam yakni penyandang disabilitas. Disabilitas meliputi keterbatasan fisik, mental, serta fisik dan mental, yang berakibat kepada ketidakmampuan seseorang tersebut untuk melakukan aktivitas di lingkungannya yang terhambat oleh fasilitas yang belum layak, sehingga menjadikannya disabled (lumpuh/ tidak dapat bergerak bebas), sehingga muncul istilah disabilitas yang saat ini dipakai oleh penyandang difabel atau penyandang disabilitas. ${ }^{5}$

Penyandang disabilitas memiliki Hak Asasi Manusia yang melekat padanya sejak terlahir ke dunia ini, sama seperti manusia non-disabilitas. Oleh karena itu, keberadaan disabilitas pun harus dilindungi oleh negara, serta dihargai oleh sesama masyarakat. Undang-Undang Dasar 1945 pada pasal 28 I ayat (2) (amandemen ke-2) menyatakan bahwa, "Setiap orang berhak bebas atas perlakuan yang bersifat diskriminatif atas dasar apa pun dan berhak mendapatkan perlindungan terhadap perlakuan yang bersifat diskriminatif itu."

Bahwa selanjutnya, Hak Asasi Manusia ialah milik siapapun yang telah lahir di dunia ini, sempurna maupun tidak. Oleh sebab itu ketentuan

\footnotetext{
${ }^{3}$ BPS Kota Batam. n.d. "Jumlah Wisata Mancanegara Yang Datang Melalui Pelabuhan Udara Dan Laut Tahun 2011-2018 Di Kota Batam." https://batamkota.bps.go.id/dynamictable/2019/01/21/39/jumlah-wisatawan-mancanegara-yangdatang-melalui-pelabuhan-udaran-dan-laut-jiwa-perbulan-2011-2018.html. Diakses 13 April 2019.

4 "Wisman Ke Batam Sudah Tembus 1,6 Juta | Batampos.Co.Id." n.d. https://batampos.co.id/2019/01/08/wisman-ke-batam-sudah-tembus-16-juta/. Diakses 13 April 2019.

5 World Health Organization. 2017. "World Health Organization | Disabilities." WHO. https://www.who.int/topics/disabilities/en/. Diakses pada 13 April 2019.
} 
pada Bab XA tentang Hak Asasi Manusia (amandemen ke-2) pada Undang-Undang Dasar 1945 telah mencakup hak dasar dan pengakuan terhadap keberadaan disabilitas di Indonesia.

Dengan diratifikasinya Konvensi mengenai Hak-Hak Penyandang Disbailitas (Convention on the Rights of Persons with Disabilities) oleh Pemerintah Indonesia, tepatnya pada tanggal 30 Maret 2007 di New York yang kemudian diadopsi ke dalam hukum nasional yang dijadikan Undang-Undang Republik Indonesia Nomor 19 Tahun 2011 Tentang Pengesahan Konvensi Mengenai Hak-Hak Penyandang Disabilitas (Convention On The Rights Of Persons With Disabilities) tersebut. 6 Ratifikasi yang dilakukan Indonesia terhadap UNCRPD menunjukkan bahwa Indonesia memang sungguh-sungguh akan melaksanakan serta berpartisipasi dalam pemberian penghormatan hak-hak, kemudian melindungi, memenuhi, serta memajukan hak-hak yang dimiliki oleh penyandang disabilitas. Upaya tersebut diharapkan dapat memajukan serta mensejahterkan penyandang disabilitas di Indonesia.

Perwujudan perlindungan hukum yang diberikan yakni dengan dirumuskannya Undang-Undang Republik Indonesia nomor 8 tahun 2016 tentang Penyandang Disabilitas sebagai pengganti Undang-Undang Nomor 4 Tahun 1997 tentang Penyandang Disabilitas yang dianggap sudah tidak relevan untuk menjadi payung hukum para penyandang disabilitas saat ini di Indonesia. Meteri muatan undang-undang yang baru telah mengesampingkan belas kasihan (charity based) serta dalam pemenuhan hak-haknya telah diberikan ruang agar penyandang disabilitas dapat mengembangkan dirinya sebagai manusia bermartabat. Salah satu dari hak-hak tersebut ialah hak terkait kebudayaan dan pariwisata untuk penyandang disabilitas. Hak mengenai kebudayaan dan pariwisata untuk penyandang disabilitas ini dimuat dalam Pasal 16 huruf (a), huruf (b) dan huruf (c) Undang-Undang Nomor 8 tahun 2016 tentang Penyandang Disabilitas yang berisi sebagai berikut;

"Hak kebudayaan dan pariwisata untuk Penyandang Disabilitas meliputi hak:

a) Memperoleh kesamaan dan kesempatan untuk berpartisipasi secara aktif dalam kegiatan seni dan budaya;

b) Memperoleh Kesamaan Kesempatan untuk melakukan kegiatan wisata, melakukan usaha pariwisata, menjadi pekerja pariwisata, dan/ atau berperan dalam proses pembangunan pariwisata; dan

c) Mendapatkan kemudahan untuk mengakses, perlakuan, dan Akomodasi yang layak sesuai dengan kebutuhannya sebagai wisatawan."

\footnotetext{
6 "Undang-Undang Republik Indonesia Nomor 19 Tahun 2011 Tentang Pengesahan Convention On The Rights Of Persons With Disabilities (Konvensi Mengenai Hak-Hak Penyandang Disabilitas).” N.D. WWW.Bphn.Go.Id. Diakses Pada 19 Maret 2019.
} 
Dengan diakuinya hak tersebut maka baik pemerintah pusat beserta pemerintah daerah harus turut berpartisipasi dalam perwujudan hak tersebut sesuai dengan amanat Undang-Undang. Begitupula dengan pihak terkait yang bergerak di bidang pariwisata sangat perlu untuk mulai memikirkan bagiamana memberikan akses yang lebih baik untuk wisatawan disabilitas dalam rangka menghormati, melindungi, memenuhi, dan memajukan hak-hak penyandang disabilitas yakni salah satunya ialah hak kepariwisataan.

Penyandang disabilitas memiliki hak untuk berpartisipasi secara aktif dalam kegiatan seni dan budaya dan dalam melakukan kegiatan wisata, tentu membutuhkan infrastruktur yang mempermudah penyandang disabilitas fisik untuk mengeksplorasi tempat wisata terkait seperti pusat perbelanjaan atau mall. Mall di Batam memiliki daya tarik tersendiri bagi wisatawan sebab dapat menikmati wisata belanja hingga wisata kuliner dalam satu tempat. Namun, kurang memadainya fasilitas disabilitas di tempat wisata tersebut, tentu menghambat aktivitas yang seharusnya dapat dilakukan oleh penyandang disabilitas.

Berdasarkan latar belakang tersebut diatas penulis tertarik untuk membahas jurnal ini dengan rumusan masalah yaitu: Pertama, Bagaimana kondisi terkini terkait potensi kedatangan wisatawan disabilitas serta masalah yang timbul akibat kurangnya fasilitas untuk mempermudah akses wisatawan penyandang disabilitas fisik di Kota Batam? Kedua, Apa saja kendala dalam upaya pemenuhan hak kebudayaan dan pariwisata wisatawan dengan disabilitas fisik dalam memperoleh kesamaan dan kesetaraan serta kemudahan akses terhadap kepariwisataan di Kota Batam? dan Ketiga Upaya lanjutan apa yang dapat dilakukan pemerintah daerah bersama dengan pengelola tempat-tempat wisata di Kota Batam dalam memberikan fasilitas aksesibilitas yang lebih mumpuni, agar hak kebudayaan dan pariwisata penyandang disabilitas fisik dapat dipenuhi dengan baik dan menyeluruh?

\section{B. Metode Penelitian}

Sebelum menyusun jurnal ini, peneliti menggunakan penelitian hukum empiris. Penelitian hukum empiris sendiri memiliki arti yakni penelitian yang mencakup penelitian terhadap identifikasi hukum, dan penelitian terhadap efektifitas hukum. ${ }^{7}$

Sifat penelitian ini adalah deskriptif-kualitatif dimana data penelitian kualitatif yang bersifat deskriptif ini data-data yang dikumpulkan oleh penulis akan digunakan untuk membantu dalam menyelesaikan suatu obyek permasalahan yang dikaji yang mana mengacu pada norma-norma yang hidup dalam masyarakat. Alasan penelitian penulis akan menggunakan kualitatif dikarenakan penulis menggunakan data melalui

\footnotetext{
${ }^{7}$ Acmad, Mukti Fajar and Yulianto. Dualisme Penelitian Hukum; Normatif Dan Empiris. (Yogyakarta: Pustaka Pelajar, 2010).
} 
observasi secara langsung baik gambar maupun hasil wawancara sehingga lebih mudah untuk pembaca nantinya dalam memahami analisa tesebut.

Penelitian hukum empiris ini menggunakan data sekunder, Jenis data dua jenis yakni data primer dan data sekunder. Pada data primer, Pertama, yaitu data yang diperoleh melalui hasil penelitian di lapangan yang dilakukan secara langsung melalui pihak-pihak terkait yang berhubungan dengan kepariwisataan dan penyandang disabilitas melalui wawancara dan hasil observasi tertulis secara langsung. Sedangkan data sekunder merupakan data yang diperoleh melalui hasil penelaahan kepustakaan. Hasil daripada pencarian secara mendalam melalui literature-literatur serta bahan-bahan kepustakaan lainnya yang bersangkutan dengan permasalahan yang dipilih untuk diteliti disebut juga data sekunder. Data sekunder ini bersifat sebagai pendukung dari data primer atau sebagai pelengkap. terdapat tiga jenis bahan hukum pada data sekunder yakni Pertama bahan hukum primer yang digunakan ialah Peter Mahmud Marzuki menyatakan bahwa bahan hukum primer merupakan bahan hukum yang memiliki sifat otoriter. Sebab bahan hukum primer ini diambil dari Peraturan Perundang-Undangan, catatan-catatan resmi atau risalah pada penyusunan Peraturan Perundang-Undangan. Berdasarkan penelitian ini, Bahan Hukum Primer yang akan penulis gunakan ialah sebagai berikut:

a) Undang-Undang Dasar 1945

b) Undang-Undang Nomor 39 Tahun 1999 tentang Hak Asasi Manusia

c) Undang-Undang Nomor Nomor 11 tahun 2005 tentang pengesahan International Covenant on Economics, Social, and Cultural Rights 1966

d) Undang-Undang Republik Indonesia Nomor 19 Tahun 2011 Tentang Pengesahan Convention On The Rights Of Persons With Disabilities (Konvensi Mengenai Hak-Hak Penyandang Disabilitas)

e) Undang-Undang Nomor 8 tahun 2016 tentang Penyandang Disabilitas

f) Peraturan Menteri Pekerjaan Umum dan Perumahan Rakyat (PUPR) Republik Indonesia Nomor 14/PRT/M/2017 Tentang Persyaratan Kemudahan Bangunan Gedung

g) Peraturan Daerah Provinsi Kepulauan Riau Nomor 3 Tahun 2012 Tentang Perlindungan dan Pemberdayaan Penyandang Disabilitas.

Kedua, bahan hukum sekunder terdiri dari buku-buku hukum, jurnal hukum, karya tulis ahli hukum. Ketiga, dan bahan hukum tersier yaitu Kamus dan Ensiklopedia. 


\section{Hasil Penelitian dan Pembahasan}

\section{Kondisi Terkini Terkait Potensi Kedatangan Wisatawan Disabilitas serta Masalah yang Timbul Akibat Kurangnya Fasilitas Aksesibiltas Ramah Disabilitas di Batam}

Derasnya arus globalisasi membawa peradaban manusia ke zaman yang lebih modern dan praktis. Setiap orang berhak untuk dijamin HAM nya. Dalam upaya agar HAM tersebut terjamin, banyak sekali kendala yang harus dihadapi oleh Negara. Di Indonesia sendiri, perihal mengenai HAM sudah terkandung dalam konstitusi yakni Undang-Undang Dasar Republik Indonesia tahun 1945 dari Pasal 28A-287, dan beberapa Pasal yang amat lekat dengan penelitian ini yang termaktub dalam Pasal 28 I ayat (2), ayat (4), dan ayat (5) (amandemen ke-2) menyatakan bahwa;

“(2) Setiap orang berhak bebas atas perlakuan yang bersifat diskriminatif atas dasar apa pun dan berhak mendapatkan perlindungan terhadap perlakuan yang bersifat diskriminatif itu."

“(4) Perlindungan, pemajuan, penegakan, dan pemenuhan hak asasi manusia adalah tanggung jawab negara, terutama pemerintah."

“(5) Untuk menegakkan dan melindungi hak asasi manusia sesuai dengan prinsip negara hukum yang demokratis, maka pelaksanaan hak asasi manusia dijamin, diatur, dan dituangkan dalam peraturan perundang-undangan."

Dari Pasal 28 I ayat (2) jelas bahwa setiap orang, tanpa terkecuali, tidak boleh mendapatkan perlakuan yang diskriminatif dari pihak manapun. Karena pada Pasal 28 I ayat (4) dikatakan jelas bahwa hak asasi manusia setiap orang ialah tanggung jawab negara dan pemerintah, maka negara dan pemerintah harus melindungi, memajukan, menegakkan, dan mengupayakan pemenuhan HAM. Oleh karena itu, dalam rangka menjamin hak tersebut, pemerintah mengeluarkan Undang-Undang Nomor 39 tahun 1999 tentang Hak Asasi Manusia pada tanggal 23 September 1999.

Hak-hak di atas sinkron dengan International Covenant on Civil and Political Rights 1966 (Kovenan Internasional tentang Hak-hak Sipil dan Politik 1966), yang kemudian di adopsi Indonesia dalam Undang-Undang Nomor 11 Tahun 2005 pada tanggal 28 Oktober 2005. Penulis mengaitkan pasal tersebut dengan isi kovenan tersebut yang dituangkan dalam pasal 1 angka 1 . Artinya bahwa setiap individu memiliki hak untuk menentukan nasib diri sendiri. Berdasarkan hak tersebut, setiap individu bebas menentukan status politik dan bebas mengejar pengembangan dalam bidang ekonomi, sosial dan budaya. 
Dalam upaya untuk mengembangkan budaya, salah satu caranya ialah melalui pariwisata. Istilah "Pariwisata" pertama kali digunakan oleh Ir. Soekarno dalam suatu percakapan sebagai padanan dari istilah asing tourism. Maksud dari pariwisata ini harus disesuaikan dengan cara orang menggunakan istilah tersebut. Pariwisata dianggap sebagai suatu kegiatan yang dimana pada pelaksanaanya bertujuan untuk mendatangkan wisatawan. Hal-hal mengenai kepariwisataan ini kemudian diatur dalam Undang-undang Nomor 10 tahun 2009 tentang Kepariwisataan.

Pengembangan pribadi yang dapat dilakukan berhubungan dengan pariwisata ialah mengembangkan ilmu pengetahuan budaya. Namun, setiap orang juga memiliki hak untuk berekreasi. Orang yang melakukan wisata dinamakan wisatawan. Wisata dan wisatawan ini kemudian dihubungkan oleh pariwisata, dimana di dalamnya terdiri dari berbagai macam kegiatan yang dalam pelaksaannya, fasilitas dan layanan lainnya di sediakan oleh masyarakat bersama dengan pengusaha, pemerintah dan pemerintah daerah. Keseluruhan tersebut disebut kepariwisataan.

Dalam rangka mendatangkan wisatawan, kawasan tersebut mesti memiliki daya tarik wisata. Namun, daya tarik wisata tersebut tentu saja harus dilengkapi dengan hal-hal lainnya sehingga daya tarik wisata tersebut dapat masuk kepada destinasi wisata.

Dalam rangka mewujudkan destinasi pariwisata yang tidak hanya memiliki daya tarik wisata, namun juga kelengkapan fasilitas umum, fasilitas pariwisata, dan aksesibilitas, tentu dibutuhkan peran Pemerintah, Pemerintah Daerah, Pengusaha Pariwisata yang bekerjasama dengan masyarakat dalam mewujudkan kepariwisataan tersebut. Pada Pasal 5 Undang-Undang Kepariwisataan disebutkan bahwa kepariwisataan diselenggarakan dengan prinsip salah satunya ialah prinsip menjunjung tinggi hak asasi manusia, keragaman budaya, dan kearifan lokal.

Kemudian pada Pasal 7 Undang-undang Kepariwisataan menyatakan bahwa pembangunan kepariwisataan tentu meliputi industri pariwisata, kemudian destinasi wisata, pemasaran, dan kelembagaan kepariwisataan. Pengembangan ini penting agar prinsipprinsip kepariwisataan dapat dilaksanakan serta di evaluasi dengan lebih baik lagi di masa yang akan mendatang.

Kegiatan pembangunan pariwisata ini salah satunya seperti mengembangkan perhotelan berstandar Internasional, pemugaran tempat wisata lokal, serta pekan pariwisata yang diisi oleh stan-stan 
kerajinan, kesenian daerah, makanan daerah, dan ada pula yang menawarkan informasi tentang obyek wisata setempat. ${ }^{8}$

Batam tentu begitu erat dengan kepariwisataan, terlebih Batam terletak di posisi trategis dan berbatasan laut langsung dengan negara Singapura. Oleh sebab itu, Pemerintah Pusat berkoordinasi dengan Pemerintah Daerah dalam hal ini Pemerintah Kota Batam

Pada jajaran Pemerintah Daerah, urusan pariwisata ditangani oleh Dinas Pariwisata, namun di Batam, Dinas Pariwisata juga mengemban urusan Kebudayaan, menjadi Dinas Pariwisata dan Kebudayaan Kota Batam. Oleh sebab iu, Dinas Pariwisata dan Kebudayaan Kota Batam memiliki kewajiban sebagai yang tertera pada pasal diatas, tentu bekerjasama dengan jajaran pemerintah daerah yang dalam kaitannya dapat menyokong pengembangan kepariwisataan daerah.

Adapun tugas yang diemban Dinas Pariwisata dan Kebudayaan ialah menjadi pelaksana pemerintah daerah untuk bidang khusus pariwisata serta pelestarian budaya dalam wilayah kerjanya. Wewenang Dinas Pariwisata dan Kebudayaan inilah yang kemudian digunakan untuk terus mengembangkan sembari mengkontrol perkembangan kepariwisataan di Kota Batam.

Berdasarkan data yang penulis peroleh melalui wawancara dengan Kepala Bidang Pengembangan dan Promosi Pariwisata yakni Ibu Ratna Sari, adapun alasan-alasan yang menjadi daya tarik wisata Batam yakni:

1) Olahraga dan Sport Event, seperti bersepeda (cycling), kemudian golf, dan lainnya.

2) Shopping.

3) Meeting, Incentive, Convention, and Exhibition (MICE).

4) Agriculture dan Ecotourism.

5) Sejarah (History)

6) Cultural Heritage atau Warisan Budaya.

7) Culinary atau Kuliner.

8) Wisata Bahari.

9) Wisata Religi.

Artinya, Batam sudah memiliki potensi, dengan banyaknya alasan dan destinasi wisata serta serangkaian kegiatan wisata yang dapat dilakukan di Batam, dalam rangka rekreasi sembari menambah ilmu pengetahuan budaya.

${ }^{8}$ Soekadijo, R.G. Anatomi Pariwisata Memahami Pariwisata sebagai "Systemic Linkage", (Jakarta; Gramedia Pustaka Utama, 2000) 
Berdasarkan data yang diperoleh, kunjungan wisatawan keseluruhan ke Batam (mancanegara dan nusantara), dari rentang tahun 2015 hingga 2018 yakni sebagai berikut. Bahwa pada tahun 2015 terhitung sebanyak 1,545,818 jiwa yang berkunjung ke Batam, kemudian mengalami penurunan sebanyak 122,896 jiwa menjadi 1,422,922 jiwa pada tahun 2016. Kemudian mengalami kenaikan lagi sebanyak 84,291 jiwa sehingga kunjungan pada tahun 2017 mencapai 1,507,213 jiwa. Dan pada tahun lalu yakni tahun 2018, kunjungan wisatawan cukup signifikan yakni bertambah sebanyak 380,031 jiwa sehingga mencapai angka 1,887,244 jiwa. Untuk tahun 2019, telah terdata dari bulan Januari hingga April yakni sudah mencapai 616,329 jiwa pengunjung.

Artinya bahwa kondisi kedatangan wisatawan ke Batam sudah cukup baik sebab mengalami peningkatan dari tahun ke tahun. Sebagaimana data yang penulis peroleh melalui narasumber Dinas Pariwisata dan Kebudayaan Kota Batam, Dinas Pariwisata menggandeng dinas lain serta pihak swasta untuk terus mengembangkan potensi pariwisata Kota Batam melalui programprogram yang dirancangkan dalam kalender event.

Melalui kalender event ini, Dinas Pariwisata dan Kebudayaan menargetkan agar tahun ini, Batam diharapkan dapat menarik 2,4 juta kunjungan wisatawan. Artinya, Batam memiliki potensi yang besar untuk terus mendatangkan wisatawan. Oleh karena itu, pengembangan dari segala aspek sangat dibutuhkan untuk menambah potensi pariwisata Kota Batam dalam mencapai Pasal 4 Undang-undang Kepariwisataan, terutama yakni meningkatkan pertumbuhan ekonomi Batam, kemudian untuk memajukan kebudayaan, mengangkat citra bangsa, serta mempererat persahabatan antarbangsa.

Pengembangan kepariwisataan ini dapat di tekan salah satunya dengan mengembangkan destinasi pariwisata, dimana dalam destinasi pariwisata ini terdapat juga fasilitas umum, fasilitas pariwisata, dan aksesilibilitas. Dengan mempertimbangkan prinsip kesetaraan dan menjunjung hak asasi manusia, ketiga aspek tersebut harus dapat dimanfaatkan oleh semua orang, tanpa terkecuali, termasuk wisatawan dengan penayandang disabilitas.

Pemerintah Republik Indonesia telah meratifikasi Konvensi mengenai Hak-Hak Penyandang Disabilitas (Convention on the Rights of Persons with Disabilities) pada tanggal 30 Maret 2007 di New York. Indonesia kemudian mengesahkan Konvensi dengan disahkannya Undang-Undang Nomor 19 tahun 2011 pada tanggal 10 November 2011. Artinya Pemerintah Indonesia bersungguh-sungguh untuk menerapkan nilai-nilai pada konvensi tersebut. Oleh karena itu, Pemerintah akhirnya mengeluarkan Undang-Undang Nomor 8 tahun 2016 tentang Penyandang Disabilitas pada tanggal 15 April 2016 
dengan mencabut Undang-Undang Nomor 4 Tahun 1997 tentang Penyandang disabilitas yang dianggap sudah tak sejalan dengan paradigma serta kebutuhan penyandang disabilitas. Undang-Undang yang baru ini lebih menerapkan serta mengamalkan nilai-nilai dari Konvensi mengenai Hak-Hak Penyandang Disabilitas.

Penyandang Disabilitas kemudian diartikan sebagai orang yang mengalami keterbatasan fisik , intelektual, mental, dan/atau sensorik dalam jangka waktu yang lama, serta mengalami hambatan dan kesulitan dalam berinteraksi dengan lingkungan sekitarnya, sehingga tidak dapat berpartisipasi secara penuh dan efektif berdasarkan kesamaan hak. Penyandang disabilitas juga wajib mendapatkan kesamaan kesempatan, yang memiliki artian bahwa penyelenggara, yakni negara harus memberikan peluang dan/ atau menyediakan akses kepada Penyandang Disabilitas untuk menyalurkan potensinya dalam segala aspek.

Pada Undang-Undang Kepariwisataan, wisatawan penyandang disabilitas memiliki hak khusus yang tertera pada Pasal 21 yang berisi bahwa wisatawan dengan keterbatasan fisik (disabilitas fisik), anakanak, dan lanjut usia berhak mendapatkan fasilitas khusus sesuai dengan kebutuhannya. Hak khusus ini berdiri tanpa menghilangkan hak-haknya sebagai wisatawan, seperti yang tercantum pada Pasal 20 Undang-undang Kepariwisataan, yakni haknya sebagai wisatawan untuk memperoleh informasi yang akurat mengenai daya tarik wisata. Kemudian haknya untuk mendapatkan pelayanan sesuai dengan standar, mendapatkan perlindungan hukum dan keamanan, mendapatkan pelayanan kesehatan, perlindungan hak pribadi dan hak untuk mendapatkan perlindungan asuransi untuk kegiatan pariwisata yang berisiko tinggi.

Hak-hak ini mendukung hak-hak penyandang disabilitas sesuai dengan Pasal 16 Undang-Undang Penyandang Disabilitas mengenai hak kebudayaan dan pariwisata, pada huruf (a), yakni penyandang disabilitas berhak memperoleh kesamaan dan kesempatan untuk berpartisipasi secara aktif dalam kegiatan seni dan budaya. Kemudian pada huruf (b), penyandang disabilitas berhak memperoleh kesamaan kesempatan untuk melakukan kegiatan wisata, artinya disini ialah menjadi wisatawan. Namun, penyandang disabilitas juga berhak melakukan usaha pariwisata, menjadi pekerja pariwisata dan atau berperan dalam proses pembangunan pariwisata. Oleh karena itu, pemenuhan hak penyandang disabilitas terhadap kebudayaan dan pariwisata ini didukung oleh tersedianya hak-hak wisatawan serta hak khusus untuk wisatawan penyandang disabilitas fisik (termasuk lanjut usia). Terlebih pada huruf (c) terdapat hak untuk mendapatkan kemudahan akses, perlakuan, dan akomodasi yang layak, sesuai dengan kebutuhan penyandang disabilitas dalam meraih hak kebudayaan dan pariwisata nya. 
Menurut Sugi Rahayu (2013), Disabilitas Fisik atau kelainan fisik terdiri dari:

1) Kelainan Tubuh (Tuna Daksa).

2) Kelainan Indera Penglihatan (Tuna Netra).

3) Kelainan Indera Pendengaran (Tuna Rungu).

4) Kelainan Bicara (Tuna Wicara). ${ }^{9}$

Oleh sebab itu, dalam destinasi wisata, kesemua fasilitas harus harus dilengkapi dengan aksesibilitas. Aksesibilitas adalah kemudahan yang disediakan untuk Penyandang Disabilitas guna mewujudkan Kesamaan Kesempatan. ${ }^{10}$ Aksesibilitas memiliki asas yang dapat menjamin atas kemudahan serta aksesibilitas penyandang disabilitas. Keempat asas ini ialah mutlak harus dipenuhi, yakni sebagai berikut:

1) Asas kemudahan, yakni setiap individu dapat mencapai seluruh tempat atau gedung bangunan, yang digunakan oleh umum pada suatu lingkungan dengan mudah.

2) Asas kegunaan, yakni setiap individu dapat menggunakan atau memanfaatkan setiap tempat atau bangunan gedung yang digunakan untuk umum pada suatu lingkungan.

3) Asas keselamatan, yakni setiap gedung atau bangunan dalam lingkup lingkungan, yang telah dibangun maupun akan dibangun, wajib memperhatikan aspek keselamatan dalam penggunaannya bagi setiap orang termasuk disabilitas.

4) Asas kemandirian, yakni setiap individu harus dapat mencapai serta keluar masuk, dengan mempergunakan semua tempat atau bangunan dalam suatu lingkungan tanpa membutuhkan bantuan dari orang lain. ${ }^{11}$

Terkait hal ini, penulis menghubungkan aksesibilitas pada kepariwisataan ini dengan mengacu kepada Peraturan Menteri Pekerjaan Umum dan Perumahan Rakyat (PUPR) Republik Indonesia Nomor 14/PRT/M/2017 tentang Persyaratan Kemudahan Bangunan Gedung sebagai pengganti Peraturan Menteri PUPR Nomor 30/PRT/M/2006 Pedoman Teknis Fasilitas dan Aksesibilitas pada Bangunan Gedung dan Lingkungan.

\footnotetext{
${ }^{9}$ Sugi Rahayu, Utami Dewi, Marita Ahdiyana, "Jurnal Ilmu Sosial Pelayanan Publik Bidang Transportasi bagi Difabel di Daerah Istimewa Yogyakarta." September 2013, Vol. 10, No. 2. Hlm. 111.

${ }^{10}$ Indonesia, Undang-Undang Tentang Penyandang Disabilitas, UU Nomor 8 Tahun 2016, Pasal 1 angka 8.

${ }^{11}$ Sugi Rahayu, Utami Dewi, Marita Ahdiyana, "Jurnal Ilmu Sosial Pelayanan Publik Bidang Transportasi bagi Difabel di Daerah Istimewa Yogyakarta." September 2013, Vol. 10, No. 2. Hlm. 111.
} 
Penulis mengambil persyaratan teknis aksesibilitas pada Permen PUPR Nomor 14/PRT/M/2017 sebagai acuan standar aksesibilitas yang pada semestinya. Dalam Permen PUPR tersebut juga menyebutkan mengenai prinsip desain universal. Dimana disamping fasilitas aksesibilitas, prinsip desain universal juga perlu diterapkan dalam memaksimalkan rancangan bangunan dan fasilitisanya sehingga dapat digunakan oleh semua orang secara bersama-sama tanpa memerlukan adaptasi atau perlakuan khusus. Prinsip desain universal sesuai dengan Permen PUPR Nomor 14/PRT/M/2017 pasal 5 ayat (1).

Dalam prinsip desain universal ini sudah mencakup juga di dalamnya prinsip kemudahan akses tanpa hambatan (barrier free). Pada dasarnya, asas aksesbilitas dan prinsip desain universal ini ialah sejalan. Sebab keduanya mengedepankan mengenai kemudahan, kegunaan, keselamatan, dan kemandirian.

Namun, berdasarkan observasi yang telah penulis lakukan, masih ditemukan fasilitas dalam destinasi wisata yang kurang akan fasilitas aksesibilitas. Ada beberapa fasilitas dalam destinasi wisata yang sudah tersedia fasilitas aksesibilitas, namun masih banyak yang belum sesuai dengan asas aksesibilitas maupun prinsip desain universal, baik sebagian maupun keseluruhan.

Fasilitas dan aksesibilitas yang penulis observasi sebagian besar ialah toilet dan ram. Jika merujuk kepada Lampiran III Permen PUPR Nomor 14/PRT/M/2017, toilet mestinya dilengkapi dengan penanda yang jelas dan informatif. Namun, seperti di toilet wanita salah satu Mall di Batam untuk toilet khusus disabilitas tidak dilengkapi dengan penanda (sign). Sehingga semua pengunjung dapat memakai bilik tersebut. Namun, akan menjadi masalah jika pengunjung tidak memprioritaskan bilik tersebut untuk penyandang disabilitas, sebab diantara bilik lainnya, hanya bilit tersebut yang bisa digunakan untuk penyandang disabilitas.

Kemudian masalah lainnya yakni masih cukup banyak tempat umum yang berdasarkan observasi penulis tidak menyediakan toilet khusus disabilitas atau bilik dalam toilet tersebut yang khusus untuk penyandang disabilitas. Hal ini juga tidak sesuai dengan isi lampiran III Permen PUPR Nomor 14/PRT/M/2017. Dengan kondisi demikian, penyandang disabilitas fisik terutama pengguna kursi roda dipastikan akan mengalami kesulitan sebab luas ruang / bilik dalam toilet setidaknya harus memiliki ukuran $152,5 \mathrm{~cm}$ x $227,5 \mathrm{~cm}$ dan lebar pintu setidaknya $90 \mathrm{~cm}$ untuk dapat diakses pengguna kursi roda. Halhal tersebut masih belum penulis temui di beberapa fasilitas pada destinasi pariwisata.

Begitupula dengan bak cuci tangan atau wastafel, dimana tinggi yang disarankan ialah $85 \mathrm{~cm}$ untuk pengguna dewasa, dan $75 \mathrm{~cm}$ untuk pengguna kursi roda. Namun, pada tempat-tempat telah di observasi, 
kesemuanya memiliki tinggi bak cuci tangan yang sama. Peletakan bak cuci tangan juga harus memperhatikan ruang bawah bak agar mudah digunakan oleh pengguna kursi roda.

Kemudian untuk ram, persyaratan teknis untuk ram terdapat pada lampiran II Permen PUPR Nomor 14/PRT/M/2017. Ram digunakan sebagai hubungan vertikal antarlantai atau gedung. Kemudian terdapat juga ram pada jalur pejalan kaki atau pedestrian (curb ramp) memiliki lebar paling sedikit $120 \mathrm{~cm}$ dengan kelandaian paling besar 6 derajat. Namun di beberapa tempat seperti jalur pedestrian pada Taman Dendang Melayu dan Jembatan Barelang belum dilengkapi ram pada awalan dan akhir jalur pedestrian (gambar 23).

Lift atau elevator juga digunakan sebagai penghubung antarlantai. Kekurangan pada lift penumpang yang penulis jumpai ialah minimnya rambu, kemudian tombol dengan braille, meski di beberapa tempat sudah memiliki rambu dan tombol braille. Dari hasil observasi, penulis menemukan lift pada Nagoya Hill Mall salah satu Mall di Batam dimana lift yang menghubungkan foodcourt ke gedung parkir terdapat tiang penghalang, sehingga lift ini tentu tidak bisa digunakan oleh pengguna kursi roda. Sehingga, pengguna kursi roda harus menggunakan lift pada bagain gedung lainnya yang tidak terhubung langsung ke gedung parkir.

Kemudian yang tak kalah pentingnya ialah rambu dan jalur pemandu untuk disabilitas netra, juga masih minim. Sejauh ini, penulis hanya menemukan jalur pemandu yang terdapat pada jalur pedestrian di depan Hotel GGi dan jalur pedestrian di daerah Tanjung Uncang.

Dengan kondisi ini, destinasi-destinasi wisata tersebut belum dapat dikatakan bebas hambatan (barrier free). Economic And Social Commission For Asia And The Pacific (ESCAP) dengan studi mengenai "Barrier-Free Tourism For People With Disabilities In The Asian And Pacific Region" (Pariwisata Bebas Hambatan untuk Penyandang Disabilitas di Kawasan Asia dan Pasifik) menyatakan bahwa hambatan yang mucul dapat dilihat melalui beberapa tahapan yakni;

1) Kendala sosial dan budaya yang mendasarinya;

2) Informasi perencanaan perjalanan;

3) Hambatan transportasi;

4) Akomodasi yang dapat diakses;

5) Pengalaman tujuan.

Hambatan menciptakan pengecualian fisik, sensorik dan komunikasi untuk lingkungan pariwisata yang inklusif. Titik awal untuk meningkatkan pariwisata bebas hambatan adalah untuk 
memahami sifat daerah tujuan dan persyaratan untuk lingkungan yang benar-benar memungkinkan. Banyak negara di Asia-Pasifik tidak memiliki kode atau standar bangunan nasional untuk akses.

Studi yang dilakukan oleh ESCAP sangat membantu dalam melihat apa saja kemungkinan-kemungkinan yang membuat wisatawan penyandang disabilitas terutama fisik enggan untuk berwisata, atau tidak ingin kembali untuk kedua kalinya ke suatu tempat yang dirasa membuatnya sulit untuk menikmati kegiatan wisatanya tersebut, terlebih lagi jika hambatan tersebut dapat membahayakan dirinya. Padahal, sejatinya pengalaman dan perluasan pengetahuan budaya yang didapatkan melalui kegiatan wisata itu sangat berharga.

Oleh sebab itu, dengan memahami kondisi, menelaah masalah, serta mencari celah untuk memperbaiki, bukan suatu hal yang tidak mungkin bahwa Batam kedepannya berpotensi untuk menjadi kawasan wisata bebas hambatan.

Secara keseluruhan, bahwa benar, kurangnya fasilitas wisata yang ramah terhadap disabilitas terutama fisik, banyak menimbulkan masalah. Seperti pada wawancara yang penulis lakukan, para narasumber mengutarakan kesulitan masing-masing, mulai dari kendala sosial hingga kendala fasilitas. Dan diantaranya ialah fasilitas yang dirasa adalah fasilitas dasar yang semestinya layak untuk digunakan, yakni toilet.

Namun, suara tersebut tidak sampai terdengar ke penyedia fasilitas aksesibilitas. Sehingga, yang seharusnya penyediaan fasilitas aksesbilitas itu menjadi prioritas seperti amanat undang-undang, pada kenyataannya dijadikan opsi kesekian.

Jika dikaitkan dengan Teori Keseimbangan yang dikemukakan Kranenburg, setiap orang menerima keuntungan sebanyak apa yang telah ditentukan (pada undang-undang atau peraturan lainnya), begitu pula kerugian yang akan diterima sesuai dengan apa yang ditentukan. Artinya, jika di undang-udang begitu banyak hak-hak untuk penyandang disabilitas, serta beratasnamakan kesetaraan, maka itulah yang harus setiap penyandang disabilitas dapatkan, yakni dianggap setara dengan lainnya.

Namun, berkat potensi pariwisata yang dimiliki Batam, wisatawan penyandang disabilitas, serta narasumber-narasumber yang menjadi perwakilan dari kerabat penyandang disabilitas menyatakan keinginannya untuk terus dapat berkunjung ke Batam. Dengan begitu, narasumber-narasumber berharap pemerintah dapat terus membenahi, menambah fasilitas dan aksesbilitas, agar mereka dalam melakukan kegiatan wisata dapat mengambil manfaat dari kegiatan wisata tersebut dengan nyaman, aman, setara dengan non-disabilitas, dan diharapkan agar dapat segera mandiri. 
2. Kendala dalam upaya pemenuhan hak budaya dan pariwisata wisatawan dengan disabilitas fisik dalam memperoleh kesamaan dan kesetaraan serta kemudahan akses terhadap kepariwisataan di Kota Batam

Penyelenggaraan kepariwisataan harus diiringi dengan upaya untuk terus memperbaiki kualitas fasilitas dan aksesibilitas guna menyokong pertumbuhan pariwisata yang lebih setara dan menjunjung tinggi hak asasi manusia.

Hak asasi manusia kemudian di kelompokkan kedalam beberapa bagian yakni hak-hak sosial, ekonomi, dan budaya. Namun, dalam pelaksanaannya, banyak pelanggaran yang terjadi dalam penegakan hak-hak asasi manusia tersebut. Tiga macam pelanggaran terhadap hak-hak sosial, ekonomi, dan budaya ialah sebagai berikut;

1) Pelanggaran akibat ketidaksanggupan negara untuk melaksanakan kewajibannya dalam mewujudkan penghormatan, perlindungan, serta pelaksanaan terhadap hakhak ekonomi, sosial, serta budaya.

2) Pelanggaran akibat perilaku pejabat negara atau pihak-pihak yang tidak diatur melalui peraturan yang ada di negara, yang melanggar hak-hak ekonomi, sosial, dan budaya secara langsung dan nyata.

3) pelanggaran akibat adanya pembiaran atas tindakan yang melanggar hak ekonomi, sosial, dan budaya oleh negara, atau akibat dari gagalnya pemerintah dalam pengambilan langkah lanjutan yang diperlukan sebagai bentuk pelaksanaan kewajiban atas hukum.

Kewajiban untuk melindungi, mengharuskan negara untuk mencegah pelanggaran hak tersebut oleh pihak ketiga, pelanggaranpelanggaran yang dilakukan tersebut memiliki tolak ukur, artinya tidak semata-mata langsung sah dianggap melanggar hanya karena salah satu unsur tidak terpenuhi.

Seperti pada poin pertama, dinyatakan melanggar hak asasi manusia jika gagal dalam memenuhi kewajiban untuk menghormati, melindungi, dan melaksanakan hak-hak ekonomi, sosial, dan budaya. Berbicara dalam konteks negara dan penyelenggaraan pemerintahan dengan adanya Peraturan Daerah Provinsi Kepualauan Riau Nomor 3 tahun 2012 tentang Perlindungan dan Pemberdayaan Penyandang Disabilitas, bisa dikatakan bahwa pemerintah khususnya pemerintah daerah sudah melakukan upaya dan tidak melanggar poin pertama. Pariwisata salah satunya, menyangkut kepada hal budaya.

Begitupula dengan poin kedua, dimana pelanggaran pun tidak dilakukan oleh pejabat daerah, sebab pejabat daerah telah mengupayakan perwujudan dan perlindungan terhadap hak asasi 
manusia melalui dinas-dinas yang telah diatur mengenai tanggung jawab masing-masing dalam bidang ditunjuk. Seperti di Batam, Dinas Pariwisata mengupayakan program-program dalam pengembangan pariwisata. Namun harus diingat bahwa pariwisata juga harus mengakomodir hak-hak wisatawan disabilitas di dalamnya sesuai yang terkandung dalam undang-undang disabilitas maupun undangundang lainnya. Sebab disamping hak-hak nya sebagai penyandang disabilitas, perlakuan terhadap hak-hak nya sebagai wisatawan harus diwujudkan sebagai bentuk kesetaraan.

Poin ketiga pun terus diupayakan yakni upaya lanjutan yang akan dilakukan pemerintah, sebab jika tidak, pemerintah akan dianggap membiarkan tidak terpenuhinya perlindungan terhadap hak asasi manusia.

Dalam Peraturan Daerah Provinsi Kepualauan Riau Nomor 3 tahun 2012 tentang Perlindungan dan Pemberdayaan Penyandang Disabilitas pada pasal 1 angka 11 telah menyatakan bahwa kesamaan kesempatan harus diberikan kepada penyandang disabilitas dalam segala aspek kehidupan. Salah satu dari perwujudan kesetaraan tersebut ialah aksesibilitas.

Kendala inilah yang dapat memperlambat pengembangan pariwisata dalam mewujudkan pariwisata yang setara. Guna pembinaan dan pengawasan ialah badan hukum dan badan usaha sebagai mitra pemerintah daerah seperti amanat Pasal 6 Peraturan Daerah Provinsi Kepualauan Riau Nomor 3 tahun 2012 tentang Perlindungan dan Pemberdayaan Penyandang Disabilitas tersebut, turut memberikan kontribusi, sehingga pengembangan pariwisata yang setara dapat berkembang dengan cepat, terutama ialah terhadap pembangunan fasilitas aksesibilitas.

Kendala-kendala dapat dianalisa dengan teori efektivitas hukum milik Soerjono Soekanto dimana faktor-faktor yang menjadi tolak ukur keefektivitasan hukum yakni;

1) Faktor hukumnya sendiri.

2) Faktor penegak hukum menerapkan hukum.

3) Faktor sarana atau fasilitas yang mendukung penegakan hukum.

4) Faktor masyarakat.

5) Faktor kebudayaan.

Berdasarkan tolak ukur faktor pertama peraturan yang berkaitan dengan pengaturan hak penyandang disabilitas, terutama hak kebudayaan dan pariwisata ini telah diatur secara baik, sistematis, serta tidak bertentangan baik secara vertical (hierarki) maupun horizontal. Seperti pada Undang Undang Penyandang Disabilitas, dibuat dengan sinkron dengan hak-hak penyandang disabilitas pada 
Undang Undang Kepariwisataan, kemudian sesuai dengan UUD 1945, serta telah diatur pula mengenai sanksi-sanksi yang jelas atas pelanggaran yang dilakukan. Kemudian jika ditinjau melalui elemen kedua yakni aparat, maka tolak ukurnya, menurut Soerjono Soekanto ialah sebagai berikut;

Disini dapat diliat bahwa petugas yang berkaitan dengan peraturan yang penulis bahas ialah Pemerintah dan Pemerintah Daerah (Batam) berkaitan dengan Undang Undang Penyandang Disabilitas dan Undang Undang Kepariwisataan, dimana secara khusus ditangani oleh Dinas Sosial dan Dinas Pariwisata dan Kebudayaan Kota Batam, dan jajaran dinas di bidang terkait. Kemudian dalam pembuatan kebijaksanaan, Pemerintah daerah telah mengeluarkan Perda berkaitan dengan perlindungan hak penyandang disabilitas. Hal ini ialah teladan bahwa Pemerintah sudah peduli mengenai isu tersebut, dan begitupula masyarakat yang harus mulai berpartisipasi dalam perwujudan perlindungan hak untuk penyandang disabilitas.

Setiap Dinas yang ditugaskan sudah memiliki wewenang dan batasan yang jelas, sehingga dalam pemenuhan hak kebudayaan dan pariwisata ini, Dinas Pariwisata berhak mengontrol pengeluaran izinizin yang berkaitan dengan pariwisata dan kebudayaan, sedangkan untuk izin pendirian bangunan dan fasilitas aksesbilitas seharusnya dikontrol oleh Dinas Pekerjaan Umum. Namun pada kenyataannya, masih banyak gedung-gedung yang digunakan juga untuk hal kepariwisataan yang masih belum dilengkapi oleh fasilitas aksesbilitas yang layak.

Di Batam, beberapa tempat yang penulis observasi masih kurang sarana dan prasarana nya, oleh sebab itu perlu diperhitungkan untuk diadakan fasilitas penunjang hak kebudayaan dan pariwisata.

Jika ditinjau melalui faktor masyarakat, penulis menganalisa bahwa penyebab masyarakat belum mematuhi peraturan tersebut ialah dikarenakan masih kurangnya kebijakan yang dikeluarkan aparat serta masih kurangnya pengawasan aparat terhadap penegakan hukum yang ada. Padahal, peraturan yang ada sudah dilengkapi dengan ketentuan sanksi, dan sudah cukup baik dalam perumusannya. Kurangnya pengawasan dinas-dinas terkait akan berakibat pada kurangnya fasilitas yang tersedia.

Kemudian pada faktor yang terakhir mengenai budaya dimana hukum tersebut diterapkan, maka di Batam dapat dilihat bahwa budaya untuk mendahulukan atau memperioritaskan penyandang disabilitas masih kurang. Hal ini dapat disebabkan beberapa faktor, yakni masih sedikitnya populasi penyandang disabilitas yang melakukan aktivitas di luar rumah seperti berpergian ke Mall. Sehingga, tumbuh kebiasaan di masyarakat bahwa siapa cepat, ia dapat, dalam artian ,masih belum memperioritaskan orang lain yang 
lebih membutuhkan. Seperti mendahulukan lansia dan pengguna kursi roda dalam menaiki lif, atau mempersilahkan lansia dan penyandang disabilitas untuk duduk di kursi umum.

Maka berdasarkan teori efektivitas hukum Soerjono Soekanto ini, faktor-faktor yang masih cacat ialah faktor aparat, fasilitas (sarana dan prasarana), masyarakat, dan kebudayaan. Hanya faktor hukum saja yang sudah cukup baik adanya.

3. Upaya lanjutan yang dapat dilakukan pemerintah daerah bersama dengan pengelola tempat-tempat wisata di Kota Batam dalam memberikan fasilitas yang lebih mumpuni, agar hak kebudayaan dan pariwisata penyandang disabilitas fisik dapat dipenuhi dengan baik dan menyeluruh

Secara keseluruhan, Pemerintah Kota Batam telah mulai membangun fasilitas dan aksesibilitas untuk penyandang disabilitas. Oleh sebab itu, dalam tahap pembangunan ini, dibutuhkan upaya lanjutan agar kedepannya, pengembangan fasilitas dan aksesbilitas terutama dalam rangka meningkatkan pariwisata Batam dapat dilaksanakan dengan lebih baik serta memperhatikan aspek-aspek pelengkapnya, tidak hanya asal membangun saja.

Pemerintah daerah dapat menerapkan sanksi administrasi yang tegas seperti yang tertera pada pasal 98 Undang-Undang Disbilitas terkait keharusan bangunan gedung agar dilengkapi dengan fasilitas dan aksesbilitas, yang sesuai dengan Peraturan Menteri PUPR Nomor 14/PRT/M/2017 tentang Persyaratan Kemudahan Bangunan Gedung. Sesuai dengan isi ayat 3 pasal 98 Undang-Undang Disabilitas, sanksi administratif tersebut.

Kemudian pemerintah daerah mulai melaksanakan kewajiban sesuai dengan Pasal 99 Undang-Undang Disabilitas. Serta dalam rangka komunikasi dan informasi terkait pariwisata, pemerintah daerah dalam Pasal 122 dan Pasal 123 Undang-Undang Disabilitas Pemerintah wajib memfasilitasi komunikasi penyandang disabilitas sebagai bentuk atas pengakuan dan penerimaan, serta menjamin akses penyandang disabilitas terhadap informasi, baik dalam bentuk audio maupun visual. Seperti menyediakan informasi di tempat wisata menggunakan huruf braille atau menyediakan penerjemah bahasa isyarat.

Oleh karena itu, pada Undang-Undang Disabilitas Pasal 117, tertera bahwa penyelenggaraan pendataan dapat dilakukan untuk mendapatkan data yang akurat mengenai karakteristik utama serta detil terkait penyandang disabilitas yang bisa difungsikan dalam pengidentifikasian serta mengatasi kesulitan yang dihadapi oleh penyandang disabilitas dalam perolehan haknya, serta dapat membantu perumusan dan implementasi kebijakan penghormatan, 
pelindungan, dan pemenuhan hak penyandang disabilitas. Penyelenggaraan ini dikoordinasikan melalui kementrian bidang sosial dengan perwakilan Dinas di Daerah, bersama dengan Badan Statistik setempat yakni Batam.

Pendataan ini sangat berguna untuk menentukan langkah selanjutnya yang dapat dilakukan dengan merumuskan serta merancangkan implementasi untuk mengatasi hambatan bagi wisatawan disabilitas dalam memperoleh hak-hak kebudayaan dan pariwisata sekaligus hak-haknya sebagai wisatawan.

Sesuai dengan Pasal 135 Undang-Undang Disabilitas, pendanaan dari pelaksanaan penghormatan, pelindungan dan pemenuhan hak penyandang disabilitas, dalam hal ini wisatawan penyandang disabilitas untuk hak kebudayaan dan pariwisatanya dapat bersumber dari anggaran pendapatan daerah yang dialokasikan untuk membangun destinasi-destinasi pariwisata di Batam.

Selain itu upaya lanjutan yang dapat dilakukan dinas-dinas yang berikaitan dalam penegakan hak penyandang disabilitas ini, perlu melakukan mobilisasi yang lebih sering seperti melakukan penyuluhan di publik (mall) atau ketika sedang masa pameran, atau bahkan ke sekolah-sekolah dan perguruan tinggi, agar masyarakat luas lebih awam terhadap hak-hak yang dimiliki penyandang disabilitas, serta agar masyarakat mengenali dan turut berpartisipasi dalam membantu penyandang disabilitas untuk memperoleh hak-hak nya.

Namun, dalam menerapkan peraturan-peraturan tersebut, perlu menilai kembali keefektifitasan peraturan menggunakan teori efektivitas hukum Soerjono Soekanto, untuk mengupayakan penegakan hukum terutama bagi aparat dalam mematuhi peraturan yang ada dengan tegas. Dengan begitu, faktor lainnya akan saling menopang satu sama lain dalam penegakannya.

\section{Kesimpulan}

Berdasarkan hasil penelitian yang penulis kaitkan dan analisa dalam pembahasan sebelumnya, maka penulis dapat menyimpulkan hal-hal sebagai berikut untuk menjawab rumusan masalah yang penulis susun dalam penelitian ini;

1. Kondisi terkini terkait potensi kedatangan wisatawan disabilitas secara khusus tidak dapat diukur sebab tidak adanya pendataan yang valid. Namun secara keseluruhan, Dinas Pariwisata dan Kebudayaan, bersama jajaran Dinas dan Pemerintahan Kota Batam tengah berupaya mengembangkan potensi kedatangan wisatawan secara keseluruhan melalui program-program yang dirancangkan, dan berdasarkan hasil pengembangan destinasi pariwisata, kedatangan wisatawan keseluruhan terus mengalami peningkatan dalam 4 tahun ini. 
Pengembangan destinasi pariwisata ini berkaitan dengan fasilitas umum, fasilitas pariwisata, dan aksesibilitas. Untuk menjamin tercapainya hak penyandang disabilitas sebagai wisatawan dalam memenuhi hak kebudayaan dan pariwisata, maka dalam pembangunan aksesibiltas dan fasilitas lainnya harus sesuai dengan Peraturan Menteri Pekerjaan Umum dan Perumahan Rakyat (PUPR) Republik Indonesia Nomor 14/PRT/M/2017 tentang Persyaratan Kemudahan Bangunan, agar asas-asas aksesibiltas dapat tercapai. Berdasarkan hasil wawancara penulis dengan para narasumber, kurangnya fasilitas dan aksesbilitas memang mengganggu. Terlebih berdasarkan studi Economic And Social Commission For Asia And The Pacific (ESCAP) dala, studi mengenai "Barrier-Free Tourism For People With Disabilities In The Asian And Pacific Region" (Pariwisata Bebas Hambatan untuk Penyandang Disabilitas di Kawasan Asia dan Pasifik), kurangnya fasilitas dan aksesbilitas dapat menyebabkan urungnya niatan wisatawan dengan disabilitas untuk berkunjung ke suatu negara. Namun mereka berharap agar kedepannya pemerintah terus memperbaiki fasilitas aksesbilitas tersebut sebab Batam memiliki banyak potensi dalam kepariwisataan yang akan terus menarik minat para wisatawan untuk terus berkunjung ke Batam.

2. Kendala dalam upaya pemenuhan hak kepariwisataan wisatawan dengan disabilitas fisik dalam memperoleh kesamaan dan kesetaraan serta kemudahan akses terhadap kepariwisataan di Kota Batam ialah belum terpenuhinya sebagian kewajiban yang harus dilakukan pemerintah daerah tingkat provinsi dalam membantu dan memfasilitasi pemerintah daerah kabupaten/kota dalam mengatasi permasalahan terkait penyelenggaraan pemenuhan hak-hak penyandang disabilitas, serta belum dilaksanakannya kewajiban pemerintah dalam membina dan mengawasi penyelenggaraan perlindungan penyandang disabilitas. Kendala yang timbul akibat tidak dijalankannya kewajiban tersebut ialah ketiadaan data mengenai kunjungan wisatawan disabiilitas yang menyebabkan tidak terdengarnya masalah-masalah yang ada pada lapangan. Sehingga kemudian tidak ada perancangan implementasi yang khusus untuk menyelesaikan permasalahan terkait minimnya fasilitas aksesbilitas serta fasilitas aksesbilitas yang sudah ada belum memadai untuk wisatawan disabilitas. Dengan tidak adanya solusi untuk menyelesaikan permasalahan tersebut, maka pengembangan fasilitas aksesbilitas pada destinasi pariwisata akan melambat, yang akan menimbulkan menurunnya minat wisatawan penyandang disabilitas untuk berwisata ke Batam, bahkan dapat membahayakan wisatawan dengan disabilitas fisik yang berkunjung.

3. Upaya lanjutan yang dapat dilakukan pemerintah daerah bersama dengan pengelola tempat-tempat wisata dalam memberikan fasilitas aksesibilitas yang lebih mumpuni yakni melaksanakan sanksi-sanksi 
yang terdapat pada Undang-Undang Disabilitas, khususnya pada Pasal 98 agar pembangunan fasilitas aksesbilitas dapat terus dilakukan dan dikembangan demi menuju pariwisata bebas hambatan. Sanksi ini harus dijalankan dengan tegas, telebih terkait izin pendirian bangunan serta sertifikat laik fungsi. Upaya lainnya yakni penyediaan akses untuk penyandang disabilitas terhadap komunikasi dan informasi. Sebab pembangunan fasilitas dan aksesbilitas perlu didukung dengan adanya komunikasi dan penyediaan informasi menggunakan melalui bentuk yang mempertimbangkan kebutuhan penyandang disabilitas. Dan yang terakhir ialah pendataan, sebab pendataan akan menjadi pintu dari perumusan penyelesaian masalah yang dihadapi terkait pemenuhan hak kebudayaan dan pariwisata penyandang disabilitas fisik di Kota Batam. 


\section{Buku:}

\section{Daftar Pustaka}

Acmad, Mukti Fajar dan Yulianto. 2010. Dualisme Penelitian Hukum; Normatif Dan Empiris, Yogyakarta: Pustaka Pelajar.

Asshiddiqie, Jimly. 2008. Menuju Negara Hukum Yang Demokratis, Jakarta: Sekretariat Jenderal dan Kepaniteraan Mahkamah Konstitusi.

Cholid, Narbuko dan Abu Achmadi, 2001, Metodologi Penelitian, Bumi Aksara. Jakarta.

Economic And Social Commission For Asia And The Pacific, 2003, Barrier-Free Tourism For People With Disabilities In The Asian And Pacific Region, New York: United Nations Publication.

Effendi, Masyhur, 1994, Dimensi Dan Dinamika Hak Asasi Manusia Dalam Hukum Nasional Dan Internasional, Jakarta: Ghalia Indonesia.

Evandri, Masyur Effendi dan Taufani Sukmana, HAM Dalam Dimensi/Dinamika Yuridis, Sosial, Politik, Bogor: Ghalia Indonesia.

Evandri, Masyur Effendi dan Taufani Sukmana, HAM Dalam Dimensi/Dinamika Yuridis, Sosial, Politik, Bogor: Ghalia Indonesia.

Husein Umar, 2005, Metode Penelitian Untuk Skripsi dan Tesis Bisnis, Jakarta : Raja Grafindo Persada.

Koentjaraningrat, 1983, Metode - Metode Penelitian, Jakarta : Gramedia.

Marzuki, Peter Mahmud, 2010, Penelitian Hukum, Jakarta: Kencana

M.Syafi'ie, dkk, 2014, Potret Difabel Berhadapan dengan Hukum Negara, Yogyakarta: SIGAB.

Nursyamsi, Fajri, 2015, Menuju Indonesia Ramah Disabilitas, Jakarta: PSHK.

Riyadi, Eko, 2012, Vulnerable Groups: Kajian Dan Mekanisme Perlindungannya, Yogyakarta: PUSHAM UII.

Soekadijo, R.G., 2000, Anatomi Pariwisata Memahami Pariwisata sebagai "Systemic Linkage", Jakarta: Gramedia Pustaka Utama.

Soekanto, Soejono, 1986, Pengantar Penelitian Hukum, Jakarta: UI Press.

Tatang, Amirin, 1990, Menyusun Rencana Penelitian, Jakarta : Rajawali

Waluyo, 1992, Menetapkan Dan Merumuskan Masalah Dalam Kegiatan Penelitian (Makalah Latihan Jabatan Metodologi Penelitian Bagi Tenaga Edukatif). Semarang: Semarang, UNTAG. 


\section{Peraturan Perundang-Undangan:}

Indonesia. Undang-Undang Dasar 1945.

Indonesia. Undang-Undang Hak Asasi Manusia, UU No.39 tahun 1999.

Indonesia. Undang-Undang tentang Pengesahan International Covenant on Economics, Social, and Cultural Rights 1966, UU No. 11 tahun 2005.

Indonesia. Undang-Undang Kepariwisataan, UU No.10 tahun 2009.

Indonesia. Undang-Undang tentang Pengesahan United Nations Convention on The Rights of Persons with Disabilities, UU No.19 tahun 2011.

Indonesia. Undang-Undang Penyandang Disabilitas, UU No.8 tahun 2016.

Menteri Pekerjaan Umum dan Perumahan Rakyat, Peraturan Menteri Pekerjaan Umum dan Perumahan Rakyat Republik Indonesia tentang Persyaratan Kemudahan Bangunan Gedung, No. 14/PRT/M/2017

Dewan Perwakilan Rakyat Daerah Provinsi Kepulauan Riau, Peraturan Dearah Provinsi Kepulauan Riau tentang Perlindungan dan Pemberdayaan Penyandang Disabilitas, No. 3 tahun 2012.

\section{Jurnal, artikel, dan internet:}

Arti Kata Wisatawan - Kamus Besar Bahasa Indonesia (KBBI) Online. n.d. https://kbbi.web.id/wisatawan. Diakses pada April 18, 2019.

Arti Kata Objek Wisata Menurut Kamus KBBI Online, Makna Kata Dari Kamus Besar Bahasa Indonesia. n.d. https://kbbi.kata.web.id/objekwisata/. Diakses pada April 18, 2019.

BPS Kota Batam. n.d. "Jumlah Wisata Mancanegara Yang Datang Melalui Pelabuhan Udara Dan Laut Tahun 2011-2018 Di Kota Batam.” https://batamkota.bps.go.id/dynamictable/2019/01/21/39/jumlahwisatawan-mancanegara-yang-datang-melalui-pelabuhan-udarandan-laut-jiwa-perbulan-2011-2018.html. Diakses pada April 13, 2019.

DPA - The Disabled People's Association.” n.d. https://www.dpa.org.sg/resources/accessible-singapore-fortourists/. Diakses pada April 13, 2019.

Jim Mimi Institute, Disability Sensitivity for Better Services, Mimi Institute, Jakarta, 2012 